\title{
The Armed Forces' Development at the Beginning of the Twenty-First Century from the Polish Perspective
}

\author{
Stanisław Zajas *
}

\section{Introduction}

The turn of the twenty-first century is a period of very important and decisive changes in international politics, particularly in the security arena, both in relation to the global system and to individual countries and societies. This dynamic process of change is above all connected with the dissolution of the Warsaw Pact and the expansion of security and economic development, especially in Europe. Many countries' achievement of independence on democratic principles, combined with the significant enlargement of NATO and the European Union, has increased the sense of integration and safety as perceived by many nations in the region. The division of the world into two opposing blocs disappeared, and the notion of the Cold War is now primarily considered only in historical perspective. However, these changes do not necessarily mean that we live in the world without threats. Although the probability of the outbreak of an armed conflict on the global scale is very low, new security threats have emerged. The unsettling quality of these threats lies in their asymmetric character, which means that it is very often difficult to identify a particular enemy, rendering them hard to combat. However, it should be stressed that, although these threats may originate in remote areas of the globe, they may also have a local impact through the increasingly omnipresent character of the worldwide communication networks that lie at the root of globalization.

Such a situation has required a revision of many nations' approach to security problems, both on the global and national scales. Poland is a member state of both the North Atlantic Treaty Organization (NATO) and the European Union (EU). Because of Poland's participation in these regional organizations, its security level has increased. Despite this enhanced security (especially in the Euro-Atlantic area), however, it is still necessary for individual countries to have their own armed forces, which represent an important tool to pursue politics. Within the arrangement of NATO and the $\mathrm{EU}$, these forces must be capable of both defending their own territory in case of an act of aggression on any NATO state (as is called for within the framework of collective defense) and of participating in a wide range of crisis response operations outside the borders of the EU or NATO.

So what should these armed forces be like in the first decades of the new century? What kind of threats should they be ready to confront? What requirements should they fulfill? This article will attempt to provide answers to these questions. These considerations have a universal character, but here they will be addressed mainly to the issue of the development of the Polish military as seen through the lens of NATO, while also

Col. Stanisław Zajas (ret.) is an Associate Professor and Deputy Rector for Science and Research at the National Defense University in Warsaw, Poland. 
taking into consideration European conditions. The Polish approach to the requirements and directions for the development of the Polish Armed Forces' at the beginning of the twenty-first century is presented against this background.

\section{Contemporary and Future Threats in the Context of Changes in the Global Security Environment}

After 1990, the global political and military environment changed dramatically. The most significant and crucial events driving these changes stemmed from the dissolution of the Warsaw Pact and the introduction of democracy in most countries in Central and Eastern Europe. Consequently, the Berlin Wall fell, and the two German states united; Hungary, the Czech Republic, and Poland joined NATO in 1999; and nine other countries from the former Warsaw Pact followed suit in ensuing years. As a result of this process of integration, the level of security in European countries increased significantly, and it is currently extremely unlikely that an armed conflict on a large scale would emerge within Europe. Nevertheless, new threats have appeared that are of global scope and importance. Moreover, the lack of symptoms of a global armed conflict does not equal achieving an era of permanent peace. So what will be the most significant future threats that will influence the deployment of the armed forces, and the development of the components that constitute them? How will the idea of these threats be expressed?

Analyses of official documents that include evaluations of contemporary and forecasts of future threats as they relate to the development of both the political and military situations show that the primary threats involve terrorism, proliferation of weapons of mass destruction (WMD), regional conflicts, the collapse of certain countries (resulting in so-called failed states), or organized crime. ${ }^{1}$

Terrorism is currently the biggest and most unpredictable threat facing people living in widely disparate parts of the globe. It affects the openness and tolerance of communities in a direct and negative way. ${ }^{2}$ In spite of the great resources that have been directed against terrorism, the significance of this threat is most likely not going to decrease in the future, due to the fact that terrorists often have substantial funds at their disposal, are able to remain connected via modern communication networks, and are determined to take advantage of any kind of violence that will tend to inflict massive losses and create a constant threat.

1 Strategia bezpieczeństwa narodowego Rzeczpospolitej Polskiej (National Security Strategy of the Republic of Poland) (Warsaw: Ministry of National Defense, 2003), 2; Strategia bezpieczeństwa narodowego Rzeczpospolitej Polskiej (National Security Strategy of the Republic of Poland) (Warsaw: Ministry of National Defense, 2007), 6-10, 14-15; Waldemar Czarnecki, and Stefan Czmur, "Przyszłość sił zbrojnych RP: miejsce Polski w Euroatlantyckich strukturach bezpieczeństwa" ("Future of the Polish Armed Forces: Poland's Place in Euro-Atlantic Security Structures"), 1; presented at the conference Polska wizja przyszłego pola walki. Wymagania i potrzeby (Polish Vision of the Future Battlefield: Requirements and Needs), hosted by the Polish Ministry of National Defense, Warsaw, 2004.

2 NATO, "Prague Summit Declaration," available at www.nato.int/docu/pr/2002/p02-127e.html. 
The proliferation of WMD and weapon systems to carry them is currently viewed as a threat to individual countries, entire regions, and also, in special circumstances, to the whole global order. Consequently, numerous non-democratic states are presently carrying out research in order to create WMD and delivery systems. For authoritarian countries, having WMD opens up the possibility to put pressure on the world security community, and to create a threat in remote regions. North Korea, Iran, and Pakistanall of which have conducted research on such weapons - represent a threat to Europe and to the more developed countries in Asia and the Americas. This situation will require using not only measures of political pressure, but also undertaking steps that combine political pressure and military deterrence.

Despite the fact that regional conflicts will occasionally emerge far away from our countries, they may affect the security situation around the world. These conflicts are often based on religious problems, struggles for power, and long-standing traditional antagonisms. Averting such conflicts using political means is difficult, and often requires committing armed forces in order to enforce resolutions passed by the international community (whether within the forum of the United Nations, or various regional security frameworks).

Another threat that is currently present and is likely to increase in the future is that posed by situations connected with the collapse of countries due to corruption, dependence on the power of weak state institutions, or the loss of the ability to govern. Somalia, Liberia, and Afghanistan's takeover by the Taliban have been prime examples of such "failed states," which collapsed as a result of the fall of state institutions and other factors.

Europe is and probably will remain the primary target of international organized crime. Nonetheless, this threat is and will continue to be prevalent for all continents to a certain extent. It most often takes the form of smuggling drugs, women, illegal immigrants, and weapons, but also includes other modes of criminal activity. Combating organized crime requires the engagement of a wide range of state security bodies, since the activities engaged in by these criminal networks involve crossing borders in a variety of ways and for a variety of purposes.

During the Cold War, Poland's traditional perception of its own defense was based on the threat of being invaded. The character of these new threats demand that the first line of defense against them will take place primarily outside Poland's own borders. Contrary to the massive military threats from the Cold War period, each new threat does not have a strictly military manifestation. Counteracting them requires various measures, including but not limited to military assets.

When considering Poland's security, these new threats mean that Poland will need to be an active participant in the efforts undertaken by the international community to counteract the emergence of the threats discussed above, and to combat them in case they appear. As is underscored in Wizja Sit Zbrojnych Rzeczpospolitej Polskiej-2030 ${ }^{3}$

Wizja Sit Zbrojnych Rzeczpospolitej Polskiej - 2030 (The Polish Armed Forces' Vision 2030) (Warsaw: Ministry of National Defense, 2008), 7. 
(The Polish Armed Forces' Vision - 2030), the processes of political and military integration within NATO and political, economic, and military integration within the European Union are the primary factors that help decrease the possibility of destabilization or conflict in Poland's direct neighborhood. This document also stresses that, due to the unpredictability of the global security environment, one cannot rule out the possibility that new threats may emerge in Poland's "near abroad" in the next twenty years. However, the likelihood that such a threat would emerge in the form of a traditionally understood invasion connected with the tendency to occupy the territory of the country seems very low.

Owing to the participation of units from the Polish Armed Forces in stabilization and peace support operations around the world, terrorist attacks and threats will be more likely to occur. In addition, there will also be threats resulting from natural, industrial, or ecological disasters in Poland and its neighborhood. Therefore, increasing Poland's importance as a reliable partner and member of NATO and the EU will be a substantial contribution to the world and European security systems. Poland will aim to solidify this more prominent role through engagement in common defense issues and the extension of these organizations' defense capabilities. ${ }^{4}$

\section{The Polish Armed Forces' Transformation in the Context of their Participation in Future Military Operations}

The need to have greater capabilities to counteract threats means that Poland's military needs to be transformed into a more flexible and mobile force that will be more capable of providing effective defense, according to a varying scale of threats. ${ }^{5}$ NATO's use of sufficient (necessary) components assigned by cooperating countries seeks to eliminate the duplication of assets and increase the forces' potential. While increasing capabilities in various areas, Poland should also consider that it will face a wider range of military missions.

The emergence of new military and civilian threats required NATO to adjust its political and military assumptions to meet these new conditions. After the terrorist attacks of 11 September 2001, it was necessary to develop further directions of change in the Alliance's operational concept that would take into account the new security environment.

Ibid., 8.

Armed forces transformation is the process of their permanent adjustment to changes taking place in the security environment. The idea of this process rests in the constant search for and introduction of changes in all areas of the armed forces' functioning and their environment. Its range involves not only armed forces' organization and functioning, but also such areas as technical modernization, financing, and relations with the state and with civil society. See Marek Ojrzanowski, "Kierunki rozwoju sił zbrojnych - podejście polskie" ("Directions of Armed Forces' Development - Polish Approach"), in Profesjonalizacja Sit Zbrojnych Rzeczpospolitej Polskiej (Professionalization of the Polish Armed Forces), Zeszyty Naukowe, special issue 2 (71)A (Warsaw: National Defense University, 2008): 41-42. 
The principles that ensure security for the Alliance's member states are explicit: an attack on any NATO state means an attack on all its members. According to Article 5 of the Washington Treaty, NATO's multinational armed forces must be ready to deter or conduct defense on the Alliance's territory. However, NATO's armed forces must be also prepared to prevent conflicts and carry out crisis response operations outside NATO territory (so-called non-Article 5 operations). It is estimated that conducting crisis response operations beyond NATO's boundaries will be the most common deployments in the future. It must be stressed that in the short term, engagement in crisis response operations in order to resolve conflicts will often require the projection or use of military force, in addition to diplomatic efforts and political pressure. According to Article 5, these military efforts may be carried out under the rubric of collective defense or military deterrence. Yet, under the category of crisis response situations also peace support operations may be carried out as well as other crisis response operations that may include military assistance operations aimed at supporting civil authorities; operations connected with the alleviation of the results of natural disasters and calamities; non-combatant evacuation operations; search and rescue operations; withdrawal operations; and sanctions and embargo enforcement operations. ${ }^{6}$

Therefore, the primary area of the armed forces' use in the future will be operations defined under NATO doctrine as peace support operations. ${ }^{7}$ It may be assumed that such peace operations will most probably be carried out to support the activities of international security organizations (especially the UN and OSCE), and they will focus on conflict prevention and containment, as well as on creating a stable international situation.

Future crisis situations that pose a threat to international peace and security and that require the use of armed forces within peace operations will also require the provision of humanitarian assistance. Such activities, if undertaken early enough, may avert the escalation of crisis situations and their negative consequences.

The use of the armed forces in resolving crises that are different from those that directly threaten international peace and security will include a wide range of activities undertaken to support humanitarian assistance operations, including providing aid to the victims of natural and industrial disasters and securing the functioning of search and rescue systems. Specially assigned military units may also be used to evacuate non-combatants, or to evacuate their own citizens from foreign territory when they are exposed to danger. Due to NATO's growing engagement in stabilization operations, and owing to the need to support reconstruction efforts after armed conflict termination, it can be expected that the scope of assistance provided by the armed forces to

\section{AJP-3.4 Non Article 5 Crisis Response Operations (Brussels: NSA, 2004).}

7 Witold Lidwa, "Operacje reagowania kryzysowego jako podstawowy obszar użycia sił zbrojnych" ("Crisis Response Operations as a Basic Area of Armed Forces' Use"), in Współczesne i przyszłe zagrożenia bezpieczeństwa a rozwój sił zbrojnych (Contemporary and Future Security Threats vs. Armed Forces' Development), Zeszyty Naukowe, special issue 1 (70)A (Warsaw: National Defense University, 2008): 124. 
civil authorities will expand in situations when they are not able to fulfill their basic functions.

Consequently, NATO member states should develop their military capabilities within the framework of defense transformation by preparing appropriate components of land, air, naval, and special and support forces. NATO armed forces must have sufficient combat potential and capabilities to counteract aggression directed against any of the member states. They must also maintain the required level of readiness and capabilities to deploy and achieve military success within a wide spectrum of combined Allied joint operations, in which Partners and non-NATO members may also participate.

The findings mentioned above directly concern the Polish Armed Forces and their transformation process. According to the provisions of Strategia Bezpieczeństwa Narodowego Rzeczypospolitej Polskiej ${ }^{8}$ (National Security Strategy of the Republic of Poland), the aim of the armed forces' operations in the military security area is to develop the readiness to defend the territory and sovereignty of Poland and its allies, to eliminate military threats, and to counteract possible disadvantageous changes in the military balance in the region. Poland has built its defense policy in alignment with the principle of allied solidarity and loyalty. As mentioned above, Poland's expectation is that there is little probability that a large-scale armed conflict will emerge in its region in the near future. Regional and local conflicts are more likely to occur, but Poland will not be directly involved in them. Their course and consequences may create crisis situations that may threaten to expand or turn into full-scale war. Poland must be ready to respond to crises that may provoke conflicts that require it to pursue defense tasks resulting from Article 5 of the Washington Treaty. Poland's participation in collective defense and in operations in support of UN, NATO, and EU policies in the crisis response area and in stabilization operations will be connected with the need to take an extended spectrum of threats into consideration in Polish strategic planning, particularly asymmetric threats and the new technological context.

Poland does not want to be merely a beneficiary of NATO and EU membership. As a medium-sized European country with commensurate potential, Poland has confirmed its responsibility to and solidarity with the international community by actively participating in peace and stabilization operations in Iraq, Afghanistan, the Balkans, Chad, and the Golan Heights. In the recent past Poland has been fulfilling its commitments to the Allies and coalition partners, becoming one of the most persistent and reliable states in global security operations, and making notable contributions in ensuring secu-

8 Strategia Bezpieczeństwa Narodowego Rzeczypospolitej Polskiej, 2007 (National Security Strategy of the Republic of Poland, 2007), 14-15. 
rity and in the reconstruction and rebuilding processes in the above-mentioned regions. $^{9}$

In Wizja Sit Zbrojnych Rzeczypospolitej Polskiej ${ }^{10}$ (The Polish Armed Forces' Vision), Polish military planners predict that future military operations will be carried out mainly in an international arrangement - that is, they will be planned and conducted according to decisions developed by international commands and staffs. National operations will be carried out only in crisis response operations within Poland's borders; they will be limited in space and time, and their primary goal will be to minimize the effects of the existing threat. These will be mainly operations in situations of natural, industrial, and ecological disasters. In cases of external military threats or the escalation of other threats, their task will be to create the conditions to introduce international forces. The prime form of the Polish Armed Forces' activity in the twenty-year time frame will be participation in military operations conducted outside the country under the rubric of EU, NATO, or coalition crisis response operations. They will be complemented by diplomatic and economic efforts undertaken in order to prevent and avert escalating crises or conflicts.

With regard to the future development of the Polish Armed Forces, one of the most crucial requirements will be an expeditionary operations capability. Thus part of the forces will form light units, able to deploy over long distances, thoroughly equipped in combat and logistical assets, capable of rotating and conducting operations for long periods of time. ${ }^{11}$

It must be stressed that not only proper armament and equipment will determine the quality of the Polish Armed Forces, but also first and foremost the presence of professionally prepared and extensively trained soldiers. The decision concerning the Polish Armed Forces' full professionalization made by the Polish government in August 2008 is a step in the right direction, as it takes into account the importance of achieving the above-mentioned requirements.

\section{Network-Centric Warfare versus Armed Forces Development}

New concepts of conducting military operations also directly influence the armed forces' development. A new concept of such operations, known as "network-centric warfare," was launched in the United States in the 1990s. Network-centric warfare was first defined by the team of John Garstka, David Alberts, and Frederick Stein. Ac-

9 Cezary Lusiński, “Globalne i narodowe środowisko bezpieczeństwa a przyszłe operacje z udziałem sił zbrojnych RP” ("Global and National Security Environment vs Future Operations with Armed Forces' Participation”), in Wspótczesne i przyszłe zagrożenia bezpieczeństwa, a rozwój sit zbrojnych, (Contemporary and Future Security Threats vs. Armed Forces' Development), 22-24.

10 Ibid., 11.

11 Anatol J. Wojtan, "Misje, zadania i właściwości użycia sił zbrojnych w przyszłych operacjach" ("Missions, Tasks and Features of Armed Forces' Use in Future Operations"), in Współczesne i przyszłe zagrożenia bezpieczeństwa a rozwój sił zbrojnych (Contemporary and Future Security Threats vs. Armed Forces' Development), 174-75. 
cording to the American specialists' assumptions, network-centric warfare is a way of conducting operations within which armed forces - connected by IT networks - use information asymmetries and complete situation awareness (on the strategic, operational, and tactical levels) in order to carry out fast and effective operations. It is directed toward defeating the enemy with the smallest possible own losses while making effective and economical use of own (friendly) forces. ${ }^{12}$

Network-centric warfare occupies a prominent place in NATO's doctrinal assumptions. Therefore, it has been agreed that one of the main NATO transformation aims should be to ensure that Allied armed forces' capabilities to generate information advantages - combined with the capabilities that can be achieved as a result of the network solutions applied by the Alliance-will create a basis to reach a decision advantage. The aim of implementing network-centric warfare will be to create an environment within which the sensors of information acquisition, decision makers, and effect elements can be integrated within a single common super-network, which will make it possible to find and receive information from any source "plugged in" to the network in a format and time adjusted to the recipient's needs.

With regard to the Polish Armed Forces, the general requirements for achieving the capabilities called for by the network-centric warfare concept were set forth in Wizja Sit Zbrojnych Rzeczypospolitej Polskiej - 2030 (The Polish Armed Forces' Vision 2030). According to that document, future operations will be based on the networkcentric warfare concept. Its idea is to gain a significant growth of combat power through the connection of sensors acquiring information, decision makers, and weapons systems (combat platforms) into a single uniform IT network. The consequences will include information advantages, increases in the speed of command and the pace of operations, as well as increases in armament efficiency, resistance to enemy attacks, and in the level of operation synchronization. ${ }^{13}$

The prime feature of all combat systems and equipment will be their capability to operate in a networked system, based on a modern IT platform of the multidirectional exchange of information. The network will integrate in a complex way reconnaissance means, decision makers, armament, weapons, and equipment of the remaining military elements. The reconnaissance system will be based on a wide range of multi-spectral, active and passive reconnaissance sensors. The weapon system used in network-centric warfare incorporates both manned and unmanned aerial, land, and naval vehicles (platforms). They will be equipped with state-of-the art navigation and optical systems and high-precision weapons. The Polish Armed Forces will reach full network-centric warfare capabilities gradually, mainly due to the introduction of new combat techniques into armament and equipment, and the required process of full professionalization.

12 David Alberts, John Garstka, and Frederick Stein, Network Centric Warfare (Washington, D.C.: Department of Defense, C4ISR Cooperative Research Program, 2000), 88.

13 Wizja Sit Zbrojnych Rzeczpospolitej Polskiej - 2030 (The Polish Armed Forces' Vision 2030), 14 . 


\section{Conclusions}

Most analyses of the current threat environment indicate that the character of security threats will change in the next twenty years. However, the possibility of a large-scale conflict on the global scale in the near future will remain low. The main security threats will be posed by international terrorism, uncontrolled proliferation of weapons of mass destruction, outbreaks of local conflicts stemming from religious and ethnic antagonisms or economic and social inequalities, the failure of certain states, as well as international organized crime.

These threats will most likely occur in remote areas of the globe, outside the territories of Poland, NATO, or the European Union. In order to prevent these threats and resolve the crisis situations that they may generate, international organizations - such as the UN, OSCE, or NATO - will still conduct their usual operations, although probably in a more intense way. Forces established on the basis of international organizations' resolutions will have an international character and will carry out crisis response operations. In order to participate in such operations, the Allied armed forces (including the national militaries of the member states) must possess already prepared units characterized by high mobility, short time readiness to operations, high efficiency, and the capability to conduct long-term military operations in remote operational areas. New challenges for security and defense also imply the need to change the concepts of the armed forces' development, use, equipment, and training.

Our analyses also show that future operations will be carried out according to a new concept called network-centric warfare. The idea behind this concept is to ensure information advantage through creating an information network common to all participants in a conflict. Such a network will offer a high level of battlefield awareness, and will enable the delivery of necessary and up-to-date information to all battle participants, both the decision makers and the actors in the field.

The Polish Armed Forces are and will be changing in order to achieve the capabilities necessary to defend Poland's territory effectively as well as to participate in international crisis response operations outside of the nation's borders. Reaching these requirements and capabilities will depend not only on the level of Poland's national ambitions, but also on the state's economic potential, as Poland wants not only to be active on the international stage, but to also be a reliable partner and ally that makes a significant contribution to ensuring regional and world security. 


\section{Bibliography}

AJP-3.4 Non Article 5 Crisis Response Operations. Brussels: NSA, 2004.

Alberts, David, John Garstka, and Frederick Stein. Network Centric Warfare. Washington, D.C.: Department of Defense, C4ISR Cooperative Research Program, 2000.

Czarnecki, Waldemar, and Stefan Czmur. Przyszłość sił zbrojnych RP: miejsce Polski w Euroatlantyckich strukturach bezpieczeństwa (Future of the Polish Armed Forces: Poland's Place in Euro-Atlantic Security Structures) In presented at the conference Polska wizja przyszłego pola walki. Wymagania i potrzeby (Polish Vision of the Future Battlefield: Requirements and Needs). Warsaw: Polish Ministry of National Defense, 2004.

Lidwa, Witold. "Operacje reagowania kryzysowego jako podstawowy obszar użycia sił zbrojnych (Crisis Response Operations as a Basic Area of Armed Forces' Use)." In Współczesne i przyszłe zagrożenia bezpieczeństwa a rozwój sił zbrojnych (Contemporary and Future Security Threats vs. Armed Forces' Development), Zeszyty Naukowe, 124. special is $\neg$ sue 1 (70)A ed. Warsaw: National Defense University, 2008.

Lusiński, Cezary. "Globalne i narodowe środowisko bezpieczeństwa a przyszłe operacje z udziałem sił zbrojnych RP (Global and National Security Environment vs Future Operations with Armed Forces' Participation)." Warsaw: National Defense University, 2008.

Misje, zadania i właściwości użycia sił zbrojnych w przyszłych operacjach (Missions, Tasks and Features of Armed Forces' Use in Future Operations) ." In Współczesne i przyszłe zagrożenia bezpieczeństwa a rozwój sił zbrojnych (Contemporary and Future Security Threats vs. Armed Forces' Development), 174-75. Warsaw: National Defense University, 2008.

Ojrzanowski, Marek. "Kierunki rozwoju sił zbrojnych - podejście polskie (Directions of Armed Forces' Development - Polish Approach)." In Profesjonalizacja Sił Zbrojnych Rzeczpospolitej Polskiej (Professionalization of the Polish Armed Forces), Zeszyty Naukowe, 41-42. special issue 2 (71)A ed. Warsaw: National Defense University, 2008.

Prague Summit Declaration. NATO, 2002.

Strategia bezpieczeństwa narodowego Rzeczpospolitej Polskiej (National Security Strategy of the Republic of Poland). Warsaw: Ministry of National Defense, 2003.

Strategia Bezpieczeństwa Narodowego Rzeczypospolitej Polskiej, 2007 (National Security Strategy of the Republic of Poland, 2007). Warsaw: Ministry of National Defense, 2007.

Wizja Sił Zbrojnych Rzeczpospolitej Polskiej - 2030 (The Polish Armed Forces' Vision - 2030). Warsaw: Ministry of National Defense, 2008. 